\title{
Pembelajaran Kosa Kata Bahasa Inggris dengan Media Bingo Game bagi Anak Usia Dini
}

\author{
Christiana Evy Tri Widyahening ${ }^{1 凶}$, Feri Faila Sufa ${ }^{2}$ \\ Pendidikan Bahasa Inggris, Universitas Slamet Riyadi Surakarta, Indonesia(1) \\ Pendidikan Guru Pendidikan Anak Usia Dini, Universitas Slamet Riyadi Surakarta, \\ Indonesia( 2 ) \\ DOI: $10.31004 /$ obsesi.v6i3.1341
}

\begin{abstract}
Abstrak
Penelitian ini bertujuan untuk mengetahui apakah media Bingo Game dapat meningkatkan penguasaan anak-anak usia dini di TK Nahdlotul Muslimat (NDM) Kauman Surakarta terhadap kosa kata bahasa Inggris; dan mengetahui penerapan Bingo game sebagai media dalam meningkatkan penguasaan kosa kata bahasa Inggris anak-anak usia dini di TK Nahdlotul Muslimat (NDM). Penelitian ini adalah Penelitian Tindakan Kelas yang dilaksanakan dari bulan Desember 2019 sampai bulan Februari 2020 dengan menggunakan Bingo Game sebagai medianya. Bingo Game mampu meningkatkan kemampuan anak usia dini dalam penguasaan kosa kata bahasa Inggris secara optimal. Hal tersebut dapat dilihat dari hasil pre tes yaitu 58,93, hasil post tes 1 siklus satu yaitu 69,15, dan hasil post tes 2 di siklus dua yaitu 79,21. Oleh sebab itu dapat ditarik kesimpulan bahwa Bingo Game merupakan media pembelajaran yang sangat efektif untuk digunakan dalam meningkatkan penguasaan kosa kata bahasa Inggris untuk anak usia dini.
\end{abstract}

Kata kunci: bingo game; penguasaan kosa kata bahasa inggris; penelitian tindakan kelas

\begin{abstract}
This study aimed to determine whether Bingo Game media can improve English vocabulary mastery of early childhood children at Nahdlotul Muslimat Kindergarten (NDM) Kauman Surakarta; and to determine the implementation of Bingo game as the media in improving English vocabulary mastery of early childhood children at Nahdlotul Muslimat Kindergarten (NDM). This research is a Classroom Action Research conducted from December 2019 to February 2020 using Bingo Game as the medium. Bingo Game is able to improve the ability of early childhood in mastering English vocabulary optimally. This can be seen from the results of the pre-test which was 58.93, the results of post-test 1 in cycle one was 69.15 , and the results of post-test 2 in cycle two was 79.21. Therefore, it can be concluded that Bingo Game is a very effective learning media to be used in improving English vocabulary mastery for early childhood.
\end{abstract}

Keywords: bingo game; english vocabulary mastery; classroom action research

Copyright (c) 2021 Ch. Evy Tri Widyahening, Feri Faila Sufa

$\triangle$ Corresponding author:

Email Address: christiana.widyahening@gmail.com (Surakarta, Jawa Tengah, Indonesia)

Received 4 May 2021, Accepted 30 July 2021, Published 11 August 2021 


\section{PENDAHULUAN}

Di Indonesia, bahasa Inggris memiliki peran yang sangat penting di dunia pendidikan sebagai bahasa asing pertama yang wajib dikuasai oleh siswa baik dari jenjang pendidikan usia dini sampai jenjang perguruan tinggi. Di dalam pembelajaran bahasa Inggris, ada empat ketrampilan berbahasa yang dipelajari yaitu mendengarkan (listening), berbicara (speaking), membaca (reading), dan menulis (writing). Untuk menguasai empat ketrampilan berbahasa tersebut, ada beberapa elemen kebahasaan yang mendukungnya seperti vocabulary, pronunciation, spelling, grammar, phonology, morphology, syntax dan discourse. Salah satu elemen kebahasaan yang sangat penting untuk dipelajari dan dikuasai oleh siswa sejak awal mengenal bahasa Inggris dan untuk mendukung empat ketrampilan berbahasa adalah vocabulary atau kosa kata. Kosa kata merupakan salah satu komponen atau elemen utama, selain grammar atau tata bahasa, yang memang tidak dapat dipisahkan dari empat ketrampilan berbahasa tersebut. Belajar kosakata tidak hanya menghafalkan kata-kata saja, namun juga membutuhkan kemampuan untuk mengenali kata-kata tersebut, bagaimana cara mengingatnya, bagaimana mengucapkannya dan bagaimana menggunakannya dengan tepat dan benar dalam kalimat. Hal tersebut senada dengan pendapat Wallace (Setiawan, 2019) yang menyebutkan bahwa learning foreign vocabulary is not only memorizing the words, it requires the ability to recognize words, recall, pronounce spell and use them appropriately. Kualitas yang dimiliki seseorang dalam keterampilan berbahasanya bergantung pada kualitas dan kuantitas dari kosa kata yang telah dikuasainya. Semakin banyak kosa kata yang dikuasai dan dimilikinya, semakin mudah pula ia mengembangkan empat ketrampilan berbahasa. Murcia (Lube \& Nuraeni, 2020) menyebutkan bahwa vocabulary is central to language acquisition, whether the language is first, second or foreign. Sedangkan Hatch \& Brown (Yanti, 2017) menyebutkan bahwa vocabulary refers to a list or set of words for a particular language or a list or set of words that individual speaker of a language might use. Sedangkan menurut Christiana Evy Tri Widyahening \& Rahayu (2021) kosakata adalah kumpulan kata-kata yang diketahui seseorang dan merupakan salah satu komponen sistem bahasa yang penting untuk dipelajari dalam bahasa Inggris. Jadi, dapat dikatakan bahwa kosa kata merupakan dasar atau landasan utama dalam pembelajaran bahasa asing, dalam hal ini adalah bahasa Inggris, sebagai bahasa asing pertama yang wajib dipelajari dan dikuasai oleh siswa di berbagai jenjang pendidikan. Hal tersebut juga diperkuat oleh pendapat Team Ermawati et al. (2019) bahwa vocabulary plays an important role in developing students' understanding.

Karena pentingnya peran dan kedudukan bahasa Inggris sebagai bahasa asing pertama di Indonesia, maka bahasa Inggris sudah diperkenalkan sejak dini di jenjang formal pendidikan yaitu dari jenjang pendidikan usia dini sampai jenjang pendidikan tinggi. Di jenjang pendidikan usia dini, pengenalan bahasa Inggris dimulai dengan mengenalkan kosa kata yang sederhana. Langkah awal memperkenalkan bahasa Inggris di jenjang pendidikan usia dini ini sangat tepat karena anak-anak usia dini pada rentang usia 5 - 6 tahun merupakan anak-anak yang masuk dalam kategori golden age, yang mana pada masa-masa tersebut menjadi masa yang paling efektif untuk memperkenalkan bahasa Inggris. Anak-anak usia dini akan lebih mudah menyerap pembelajaran bahasa Inggris dengan lebih baik. Hal tersebut diperjelas pula dengan pendapat Lonigan, Burgess, \& Anthony (Wahyuningsih, 2019) yang menyebutkan bahwa anak-anak usia dini diharapkan mempunyai ketrampilan dalam pengucapan bahasa yang tepat dan baik termasuk dalam bahasa Inggris. Jadi, masa golden age ini menjadi masa yang paling baik dan sesuai untuk anak-anak usia dini mengenal bahasa asing karena semua aspek perkembangan dapat dengan mudah diserap oleh anak (Nurzaman et al., 2017).

Di dalam pengenalan kosa kata bahasa Inggris kepada anak usia dini, guru dapat menggunakan berbagai media pembelajaran yang menarik dan sesuai dengan perkembangan usia anak. Secara umum, media pembelajaran sendiri menurut Sadiman (Liyana \& Kurniawan, 2019) merupakan segala sesuatu yang dapat digunakan untuk menyalurkan pesan dari pengirim ke penerima sehingga merangsang pikiran, perasaan, perhatian dan 
minat serta perhatian siswa sedemikian rupa sehingga proses belajar terjadi. Sedangkan Buckingham (Ch. Evy Tri Widyahening \& Mafiah, 2019) menambahkan bahwa media are a medium as an intervening means, instrument or agency: it is a substance or a channel through which effects or information can be arried or transmitted. Sementara Media pembelajaran yang sesuai untuk anak usia dini dapat berupa: (1) media visual yaitu media yang dapat dilihat dan lebih menekankan pada indera penglihatan; (2) media audio merupakan media yang lebih menekankan pada indera pendengaran yang dapat merangsang pikiran, perasaan, perhatian, dan keamanan anak untuk mempelajari isi tema; dan (3) media audio-visual merupakan media yang menekankan pada penggunaan indera pendengaran dan penglihatan (Rizkiani et al., 2019; Liyana \& Kurniawan, 2019). Media pembelajaran yang biasa digunakan dalam proses pengenalan bahasa Inggris adalah dalam bentuk permainan sebagai salah satu cara yang dapat menarik anak usia dini untuk ikut serta dalam proses pembelajaran tersebut dengan sukacita karena di dalamnya ada proses aktivitas yang melibatkan aturan di dalamnya, tujuan yang hendak dicapai, dan tentunya ada kegembiraan. Hal tersebut senada dengan pendapat Jill Hadfield (LIU Shuang \& LIU Jin-xia, 2015) bahwa games as "an activity with rules, a goal and an element of fun". Salah satu permainan yang menarik untuk diterapkan dalam pengenalan kosa kata bahasa Inggris adalah Bingo game. Bingo game merupakan permainan yang sangat menyenangkan apabila dapat diterapkan dengan baik oleh guru kepada anak-anak usia dini dan didukung oleh sarana yang tersedia di sekolah. Bingo game juga dapat dimainkan secara berkelompok maupun secara individu dan dapat digunakan pula sebagai media dalam pembelajaran bahasa Inggris yang sangat menyenangkan. Coco (Putri \& Kareviati, 2021) menyebutkan bahwa Bingo game can be called a holistic game, because can make the player feel enjoy the game. Bingo game dapat diterapkan pada siswa di semua jenjang pendidikan dan dapat digunakan pula oleh guru untuk melihat perkembangan belajar siswa dalam pembelajaran kosa kata. Hal tersebut juga dikemukakan oleh Richardson (Qomariyah \& Utama, 2020) bahwa Bingo game can be applied for many students, it could encourage for learn and review the students' vocabulary. Jadi, Bingo game merupakan salah satu media pembelajaran yang sangat sesuai untuk digunakan dalam proses pembelajaran kosa kata bahasa Inggris karena penerapannya mudah, menyenangkan dan mampu pula memotivasi siswa untuk belajar kosa kata. Hal tersebut senada pula dengan pendapat Gadner (Rahmasari, 2021) yang menyebutkan bahwa Bingo game is an ideal tool in assessing and teaching English especially vocabulary.

Berdasarkan hasil wawancara di TK Nahdlotul Muslimat (NDM), pelaksanaan dalam pengenalan bahasa Inggris ini sudah dilaksanakan oleh guru dengan menggunakan media permainan. Namun, media permainan yang digunakan sudah sangat umum dipakai dan setiap saat guru menggunakannya dalam proses pembelajaran tanpa membuat variasi permainan yang lain. Alhasil, anak-anak merasa bosan, tidak fokus, dan kurang bersemangat sehingga hal tersebut juga memengaruhi hasil pembelajarannya dalam bahasa Inggris. Adapun media yang biasa digunakan oleh guru dalam proses pembelajaran kosa kata bahasa Inggris adalah flash card. Bingo game menjadi media pembelajaran baru yang diperkenalkan untuk siswa usia dini di TK NDM, bahkan guru bahasa Inggris di TK NDM juga belum pernah mencobanya. Hal tersebut menjadi pengetahuan baru baik bagi guru maupun siswa usia dini yang belajar di TK NDM tentang penggunaan Bingo game. Penerapan Bingo game ini dilaksanakan untuk mengetahui bagaimana penggunaannya dalam pembelajaran kosa kata di TK NDM dan apakah dapat meningkatkan penguasaan kosa kata anak usia dini di TK NDM.

Beberapa penelitian-penelitian lain yang pernah dilakukan dan menggunakan media permainan untuk meningkatkan kosa kata bahasa Inggris anak usia dini diantaranya adalah Penggunaan permainan pesan gambar berantai untuk meningkatkan kosakata bahasa Inggris anak usia dini (Rahman \& Angraeni, 2020); Penggunaan media gambar untuk meningkatkan penguasaan vocabulary anak (Utami \& Rahman, 2020); Penerapan Permainan Scrabble Untuk Meningkatkan Penguasaan Kosakata Anak (Muspawi et al., 2020); Meningkatkan kosakata 
anak usia dini melalui permainan Chinese Whispers (Roswati, 2020); dan Meningkatkan Penguasaan Kosakata Anak Usia Dini melalui Puisi Lagu Anak (Inten, 2018). Media permainan yang digunakan dalam proses pembelajaran kosa kata bahasa Inggris di TK adalah digunakan untuk membantu anak-anak belajar bahasa Inggris dengan mudah melalui kesenangan dan kegembiraan.

\section{METODOLOGI}

Penelitian ini adalah Penelitian Tindakan Kelas. Harmer (Aisyah et al., 2019) menyebutkan bahwa penelitian tindakan atau action research is the name given to a series of procedures teachers can engage, perhaps teacher wish to improve aspect in their teaching or alternatively to evaluate the success of certain activities and procedures. Dalam hal ini, penelitian tindakan merupakan penelitian yang sistematis dan dinamis yang mana penelitian tersebut mencakup perencanaan, tindakan, pengamatan, dan refleksi. Hal tersebut senada dengan pendapat Mills (Nuraeningsih \& Rusiana, 2016) yang menyebutkan bahwa conducting a classroom action research involves four steps in each cycle: planning, acting, observing and reflecting.

Di dalam penelitian tindakan, diperlukan juga penyesuaian pendidik sebagai pihak yang melibatkan diri bersama dengan peneliti dalam penelitian untuk mencapai tujuan yaitu memahami proses belajar mengajar di kelas dan untuk membawa peningkatan yang lebih baik dalam praktik pembelajaran di kelas. Subyek penelitian adalah anak usia dini di kelas A dan kelas B TK Nahdlotul Muslimat (NDM) Kauman, Surakarta dengan jumlah keseluruhan adalah 32 anak dan dengan rentang usia 5-6 tahun. Penelitian ini dilaksanakan pada bulan Desember 2019 sampai bulan Februari 2020. Teknik pengumpulan data adalah melalui tes, pengamatan, dan wawancara. Sedangkan Teknik analisis data dilaksanakan melalui analisis data kualitatif dan analisis data kuantitatif.

\section{HASIL DAN PEMBAHASAN}

Implementasi dari Bingo Game dapat meningkatkan penguasaan kosa kata bahasa Inggris Hal ini dapat dilihat dari hasil penelitian yang menunjukkan nilai rata-rata pretes, postes 1 dan postes 2, sebagaimana ditunjukkan pada tabel 1 .

Tabel 1. Perbandingan antara rata-rata

\begin{tabular}{llll}
\hline & Pre tes & Postes 1 & Postes 2 \\
\hline Nilai Total & 1886 & 2213 & 2535 \\
Nilai rata-rata & 58,93 & 69,15 & 79,21 \\
\hline
\end{tabular}

Dari tabel 1 dapat dijelaskan bahwa terjadi peningkatan penguasaan kosakata anak usia dini dari sebelum diterapkannya Bingo game (pre tes) dan sesudah dilaksanakan tindakan pada siklus 1 (pos tes 1) dan siklus 2 (pos tes 2). Sebelum dilaksanakannya tindakan dengan menggunakan Bingo game, diadakan pre tes terlebih dahulu untuk melihat kemampuan anak dalam berbahasa Inggris, khususnya terkait dengan kosa kata. Nilai ratarata dari pre tes adalah 58,93. Dan nilai tersebut meningkat di siklus 1 menjadi 69,15 setelah diterapkannya Bingo game. Pada siklus 2, nilai rata-rata menjadi lebih tinggi dari nilai ratarata pre tes maupun pos tes 1 yaitu 79,21. Penilaian tersebut juga disesuaikan dengan pedoman penilaian kurikulum tahun 2013 yang menyatakan bahwa 1) BB memiliki arti Belum Berkembang; 2) MB memiliki arti Mulai Berkembang;3) BSH memiliki arti Berkembang Sesuai Harapan; dan 4) BSB memiliki arti Berkembang Sangat Baik. Dari hasil penelitian ini menunjukkan bahwa siswa usia dini di TK NDM memenuhi klasifikasi Berkembang Sesuai Harapan (BSH).

Dari hasil pra tes yang dipaparkan pada tabel 2, maka dapat disimpulkan bahwa ada 15 anak yang memperoleh nilai di bawah nilai 60 (rentang 30-56) dalam proses kegiatan pra siklus. Adapaun yang memperoleh nilai pada rentang 60 -73 adalah sebanyak 13 anak, 
sedangkan yang memperoleh nilai 76-80 adalah sebanyak 4 anak. Nilai tertinggi yang dicapai oleh siswa adalah 80 oleh dua orang siswa. Meskipun pada pra siklus ini ada 17 siswa yang berada pada klasifikasi BSH, namun nilai yang diperoleh masih dianggap kurang atau belum memuaskan dengan nilai rata-rata yaitu 58, 93 sehingga dilakukan perencanaan tindakan pada siklus 1 dengan menggunakan media Bingo game. Selain itu, masih ada 13 anak yang berada pada klasifikasi MB dan 2 anak berada pada klasifikasi BB, sedangkan untuk klasifikasi BSB adalah kosong atau tidak ada. Adapun klasifikasi penilaian berdasarkan pedoman penilaian kurikulum 2013 pada pra siklus ini ditunjukkan pada tabel 4.

Tabel 2. Hasil pre-tes

\begin{tabular}{lllll}
\hline No. & Nama & $\begin{array}{c}\text { Jumlah } \\
\text { Benar }\end{array}$ & Nilai & Keterangan \\
\hline 1. & RS & 21 & 70 & BSH \\
2. & AKA & 23 & 76 & BSH \\
3. & AT & 11 & 36 & BB \\
4. & ARP & 14 & 46 & MB \\
5. & AN & 14 & 46 & MB \\
6. & AMP & 15 & 50 & MB \\
7. & MKP & 20 & 66 & BSH \\
8. & OP & 18 & 60 & BSH \\
9. & N & 22 & 73 & BSH \\
10. & AW & 16 & 53 & MB \\
11. & EAP & 15 & 50 & MB \\
12. & HI & 19 & 63 & BSH \\
13. & MRM & 18 & 60 & BSH \\
14. & NA & 17 & 56 & MB \\
15. & NSO & 15 & 50 & MB \\
16. & IS & 17 & 56 & MB \\
17. & BAAS & 24 & 80 & BSH \\
18. & AAP & 17 & 56 & MB \\
19. & HKLA & 15 & 50 & MB \\
20. & HAA & 20 & 66 & BSH \\
21. & MAA & 21 & 70 & BSH \\
22. & AWM & 17 & 56 & MB \\
23. & RR & 23 & 76 & BSH \\
24. & KMS & 18 & 60 & BSH \\
25. & MAN & 20 & 66 & BSH \\
26. & MAAZ & 17 & 56 & BSH \\
27. & MFP & 24 & 80 & BSH \\
28. & RKAR & 18 & 60 & BSH \\
29. & RWSS & 13 & 43 & MB \\
30. & RPP & 18 & 60 & BSH \\
31. & VVS & 19 & 63 & BSH \\
32. & YA & 10 & 33 & BB \\
\hline & TOTAL SKOR & 1886 & \\
NILAI RATA-RATA & 58,93 & \\
\hline & & & & \\
\hline
\end{tabular}

Tabel 3. Hasil Pos-tes 1

\begin{tabular}{lllll}
\hline No. & \multicolumn{1}{c}{ Nama } & $\begin{array}{c}\text { Jumlah } \\
\text { Benar }\end{array}$ & Nilai & Keterangan \\
\hline 1. & RS & 22 & 73 & BSH \\
2. & AKA & 24 & 80 & BSH \\
3. & AT & 20 & 66 & BSH \\
4. & ARP & 16 & 53 & MB \\
5. & AN & 18 & 60 & BSH \\
6. & AMP & 20 & 66 & BSH \\
7. & MKP & 21 & 70 & BSH \\
8. & OP & 20 & 66 & BSH \\
9. & N & 23 & 76 & BSH \\
10. & AW & 23 & 76 & BSH \\
11. & EAP & 18 & 60 & BSH \\
12. & HI & 21 & 70 & BSH \\
13. & MRM & 24 & 80 & BSH \\
14. & NA & 19 & 63 & BSH \\
15. & NSO & 20 & 66 & BSH \\
16. & IS & 20 & 66 & BSH \\
17. & BAAS & 26 & 86 & BSB \\
18. & AAP & 19 & 63 & BSH \\
19. & HKLA & 21 & 70 & BSH \\
20. & HAA & 23 & 76 & BSH \\
21. & MAA & 21 & 70 & BSH \\
22. & AWM & 19 & 63 & BSH \\
23. & RR & 27 & 90 & BSB \\
24. & KMS & 22 & 73 & BSH \\
25. & MAN & 21 & 70 & BSH \\
26. & MAAZ & 18 & 60 & BSH \\
27. & MFP & 26 & 86 & BSB \\
28. & RKAR & 23 & 76 & BSH \\
29. & RWSS & 15 & 50 & MB \\
30. & RPP & 19 & 63 & BSH \\
31. & VVS & 21 & 70 & BSH \\
32. & YA & 17 & 56 & MB \\
\hline & TOTAL SKOR & 2213 & \\
& NILAI RATA-RATA & 69.15 & \\
\hline & & & & \\
\hline
\end{tabular}

Tabel 4. Klasifikasi penilaian berdasarkan pedoman penilaian kurikulum 2013

\begin{tabular}{llll}
\hline \multicolumn{1}{c}{ No. } & \multicolumn{1}{c}{ Klasifikasi } & \multicolumn{1}{c}{ Nilai } & \multicolumn{1}{c}{ Jumlah Siswa } \\
\hline 1. & BSB (Berkembang Sangat Baik) & $85-100$ & 0 \\
2. & BSH (Berkembang Sesuai Harapan) & $60-84$ & 17 \\
3. & MB (Mulai Berkembang) & $40-59$ & 13 \\
4. & BB (Belum Berkembang) & $0-39$ & 2 \\
\hline \multicolumn{4}{c}{ Jumlah Total Siswa } \\
\hline
\end{tabular}

Dari hasil pos tes 1 (tabel 3) dapat disimpulkan bahwa ada 3 anak yang memperoleh nilai diatas 85 (rentang 85-100) dalam kegiatan pos-tes 1. Sedangkan anak yang memperoleh nilai rentang 60 - 84 adalah sebanyak 26 anak, dan yang memperoleh nilai pada rentang 40-59 
adalah sebanyak 3 anak. Nilai tertinggi yang dicapai oleh siswa adalah 90 dan nilai terendah adalah 50. Pada siklus 1 ini, nilai rata-rata pos tes 1 (69.15) lebih tinggi dari nilai rata-rata pre tes (58.93).

Tabel 5. Klasifikasi penilaian berdasarkan pedoman penilaian kurikulum 2013

\begin{tabular}{|l|l|l|l|}
\hline \multicolumn{1}{|c|}{ No. } & \multicolumn{1}{|c|}{ Klasifikasi } & \multicolumn{1}{|c|}{ Nilai } & \multicolumn{1}{c|}{ Jumlah Siswa } \\
\hline 1. & BSB (Berkembang Sangat Baik) & $85-100$ & 3 \\
\hline 2. & BSH (Berkembang Sesuai Harapan) & $60-84$ & 26 \\
\hline 3. & MB (Mulai Berkembang) & $40-59$ & 3 \\
\hline 4. & BB (Belum Berkembang) & $0-39$ & 0 \\
\hline \multicolumn{2}{|c|}{ Jumlah Total Siswa } & 32 \\
\hline
\end{tabular}

Pada pos tes 1 di siklus 1 ini (tabel 5) ada 26 anak yang berada pada klasifikasi BSH, 3 anak berada pada klasifikasi BSB, dan 3 anak berada pada klasifikasi MB. Sebagian besar anak dapat menebak dan mengucapkan kata bahasa Inggris yang merujuk pada gambar yang diberikan oleh peneliti. Dalam hal mengucapkan kata bahasa Inggris, masih banyak anak yang belum secara tepat dan benar dalam mengucapkannya. Selain itu mereka mampu untuk mengingat dengan baik arti kata dalam bahasa Inggris dan bahasa Indonesia karena sebelumnya telah mempelajari kosa kata tersebut dengan menggunakan media Bingo game. Peneliti juga memberikan petunjuk apabila ada anak yang merasa kesulitan atau bingung untuk menebak gambar tersebut. Meskipun nilai rata-rata pos tes 1 sudah lebih tinggi dari nilai pre- tes dan juga jumlah anak yang ada pada klasifikasi BSH juga lebih banyak, namun sebagian besar anak masih sangat antusias untuk mempelajari kosa kata bahasa Inggris dengan menggunakan media Bingo game dan peneliti sendiri tergelitik untuk melanjutkan kegiatan pembelajaran ke siklus 2 dengan memberikan penguatan yang lebih baik tentang kosa kata bahasa Inggris dan bagaimana cara mengucapkan kata tersebut dalam bahasa Inggris yang tepat pada anak melalui Bingo game. Selain itu, peneliti menganggap bahwa nilai rata-rata yang diperoleh masih dianggap kurang atau belum memuaskan $(69,15)$ walaupun lebih tinggi dari pre tes, sehingga dilakukan tindakan lanjutan pada siklus 2 dengan tetap menggunakan media Bingo game dalam proses pembelajaran kosa kata bahasa Inggris.

Pada tabel 7, hasil pos tes 2 dapat dilihat bahwa ada 10 anak yang memperoleh nilai diatas 85 (rentang 85-100). Anak yang memperoleh nilai rentang 60 - 84 adalah sebanyak 21 anak, dan yang memperoleh nilai pada rentang 40-59 adalah tidak ada. Nilai tertinggi yang dicapai oleh anak adalah 93 dan nilai terendah adalah 60. Pada siklus 2 ini, nilai rata-rata pos tes 2 (79.21). Nilai tersebut lebih tinggi dari nilai rata-rata pre tes $(58,93)$ dan nilai rata-rata pos tes 1 (69.15).

Pada pos tes 2 di siklus 2 ini (tabel 6) ada 21 anak yang berada pada klasifikasi BSH, 10 anak berada pada klasifikasi BSB, dan pada klasifikasi MB maupun BB tidak ada atau kosong. Sebagian besar anak dapat menebak dan mengucapkan kata bahasa Inggris yang merujuk pada gambar yang diberikan oleh peneliti dengan lebih baik. Selain itu mereka semakin mampu untuk mengingat dengan baik arti kata dalam bahasa Inggris dan bahasa Indonesia.

Tabel 6. Klasifikasi penilaian berdasarkan pedoman penilaian kurikulum 2013

\begin{tabular}{llll}
\hline No. & \multicolumn{1}{c}{ Klasifikasi } & \multicolumn{1}{c}{ Nilai } & \multicolumn{1}{c}{ Jumlah Siswa } \\
\hline 1. & BSB (Berkembang Sangat Baik) & $85-100$ & 10 \\
2. & BSH (Berkembang Sesuai Harapan) & $60-84$ & 21 \\
3. & MB (Mulai Berkembang) & $40-59$ & 0 \\
4. & BB (Belum Berkembang) & $0-39$ & 0 \\
\hline & Jumlah Total Siswa & 32 \\
\hline
\end{tabular}


Tabel 6 Hasil Pos-tes 2

\begin{tabular}{|c|c|c|c|c|}
\hline No. & Nama & Jumlah Benar & Nilai & Keterangan \\
\hline 1. & RS & 23 & 76 & BSH \\
\hline 2. & AKA & 25 & 83 & $\mathrm{BSH}$ \\
\hline 3. & AT & 23 & 76 & $\mathrm{BSH}$ \\
\hline 4. & ARP & 18 & 60 & MB \\
\hline 5. & AN & 21 & 70 & $\mathrm{BSH}$ \\
\hline 6. & AMP & 22 & 73 & BSH \\
\hline 7. & MKP & 23 & 76 & $\mathrm{BSH}$ \\
\hline 8. & OP & 21 & 70 & $\mathrm{BSH}$ \\
\hline 9. & $\mathrm{~N}$ & 27 & 90 & BSH \\
\hline 10. & AW & 21 & 70 & $\mathrm{BSH}$ \\
\hline 11. & EAP & 27 & 90 & BSH \\
\hline 12. & $\mathrm{HI}$ & 20 & 66 & $\mathrm{BSH}$ \\
\hline 13. & MRM & 28 & 93 & BSH \\
\hline 14. & NA & 26 & 86 & $\mathrm{BSH}$ \\
\hline 15. & $\mathrm{NSO}$ & 24 & 80 & $\mathrm{BSH}$ \\
\hline 16. & IS & 24 & 80 & BSH \\
\hline 17. & BAAS & 28 & 93 & BSB \\
\hline 18. & AAP & 25 & 83 & BSH \\
\hline 19. & HKLA & 23 & 76 & $\mathrm{BSH}$ \\
\hline 20. & HAA & 24 & 80 & $\mathrm{BSH}$ \\
\hline 21. & MAA & 27 & 90 & BSH \\
\hline 22. & AWM & 21 & 70 & $\mathrm{BSH}$ \\
\hline 23. & RR & 27 & 90 & BSB \\
\hline 24. & KMS & 23 & 76 & $\mathrm{BSH}$ \\
\hline 25. & MAN & 22 & 73 & BSH \\
\hline 26. & MAAZ & 24 & 80 & BSH \\
\hline 27. & MFP & 28 & 93 & BSB \\
\hline 28. & RKAR & 24 & 80 & BSH \\
\hline 29. & RWSS & 19 & 63 & MB \\
\hline 30. & RPP & 27 & 90 & BSH \\
\hline 31. & VVS & 26 & 86 & $\mathrm{BSH}$ \\
\hline 32. & YA & 22 & 73 & MB \\
\hline \multicolumn{3}{|c|}{ TOTAL SKOR } & \multicolumn{2}{|l|}{2535} \\
\hline \multicolumn{3}{|c|}{ NILAI RATA-RATA } & \multicolumn{2}{|l|}{79.21} \\
\hline
\end{tabular}

\section{Pembahasan}

Penerapan Bingo game dalam pembelajaran kosa kata bahasa Inggris di TK NDM diterapkan di siklus 1 dan siklus 2. Pada pra siklus, peneliti mengumpulkan anak-anak usia antara 5-6 tahun yang berjumlah 32 siswa di dalam kelas. Peneliti memberikan pertanyaan sederhana seputar tema alat tulis, buah-buahan, dan sayur-sayuran dalam bahasa Inggris sesuai dengan materi dan media yang digunakan oleh guru sebelumnya yaitu dengan menggunakan flash card. Hal tersebut dilakukan untuk mengetahui tingkat pemahaman awal anak-anak tentang penguasaan kosa kata mereka sebelum dilaksanakan tindakan. Penerapan media Bingo game pada penelitian ini dilaksanakan di siklus 1. Bingo game merupakan permainan yang baru untuk anak-anak usia dini di TK NDM karena selama ini guru lebih banyak menggunakan media flash card untuk memberi pembelajaran kosa kata bahasa Inggris pada mereka. Bingo game yang digunakan pada penelitian ini baik itu untuk siklus 1 dan siklus 2 adalah tentang tema buah-buahan, hewan, dan tumbuhan. Media bingo game yang digunakan pada penelitian ini dibuat sendiri oleh peneliti dengan materi yang diambil dari berbagai sumber. Langkah-langkahnya adalah setelah materi dibuat dan kemudian diperbanyak, lalu materi tersebut diberikan kepada anak-anak di kelas A dan B. Selanjutnya, 
peneliti mendemonstrasikan cara bermain Bingo game. Setelah itu, anak-anak menghafalkan nama-nama buah/hewan/tumbuhan yang diberikan oleh peneliti pada kartu Bingo. Lalu berikutnya, peneliti meletakkan kartu master dari Bingo game menghadap ke atas dan kartu panggil menghadap ke bawah. Selanjutnya, peneliti mengambil salah satu kartu panggil dan mengucapkannya dengan keras dan jelas dua kali. Anak-anak harus mencoret dan memberi nomor pada gambar yang telah mereka hafalkan tersebut jika gambar itu disebut oleh peneliti. Setelah itu, anak yang telah melewati lima kata secara vertikal, horizontal atau diagonal berteriak Bingo yang artinya dia memenangkan permainan. Gambar 1, merupakan salah satu media Bingo game tema buah-buahan untuk pembelajaran kosa kata bahasa Inggris yang dibuat oleh peneliti dengan menggunakan gambar-gambar yang diambil dari sumber internet.

\section{Gambar 1. Bingo Game tema buah-buahan}

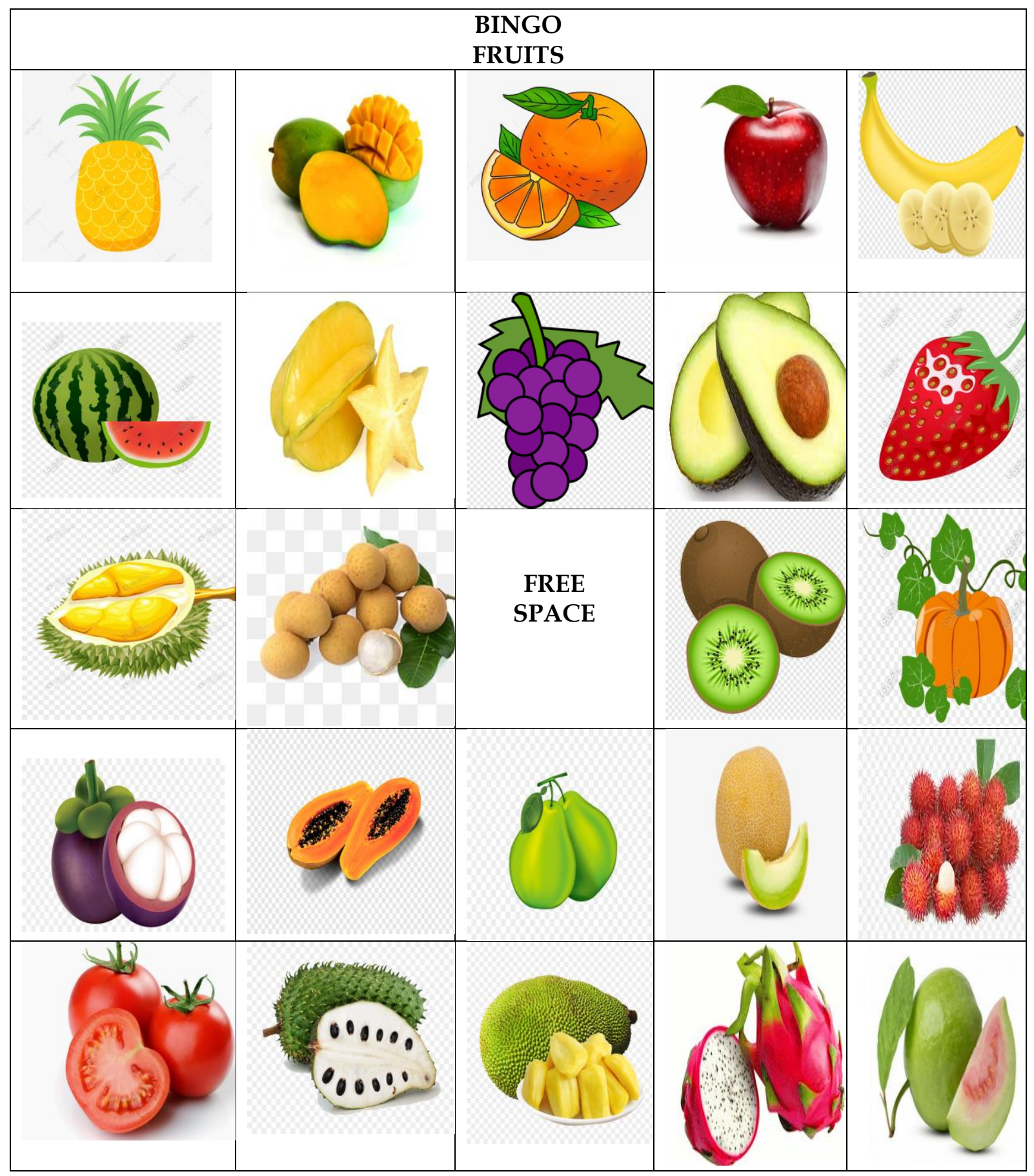


Setelah menerapkan Bingo game dalam dua siklus, peneliti melaksanakan kegiatan tes yaitu pos tes 1 dan pos tes 2 yang berhubungan dengan penguasaan kosa kata bahasa Inggris di kelas A dan B. Pada siklus pertama, peneliti melaksanakan tes setelah siswa memperoleh materi terkait dengan kosa kata bahasa Inggris dengan tema buah-buahan, hewan, dan tumbuh-tumbuhan dengan menggunakan Bingo game. Jadi, media Bingo game digunakan dalam proses pembelajaran kosa kata bahasa Inggris sehingga hal tersebut banyak menarik minat siswa untuk mengikuti pembelajaran dengan senang hati dan memudahkan mereka dalam memahami arti kata tersebut dalam bahasa Inggris dan bahasa Indonesia. Sedangkan untuk tes, peneliti memberikan gambar-gambar menarik yang diacak sesuai dengan materi yang sudah diberikan kepada siswa dan siswa diminta untuk menebak gambar-gambar tersebut dan mengucapkannya dalam bahasa Inggris.

Pada siklus 2, peneliti memberikan materi dengan tema yang sama dengan siklus 1 yaitu tentang buah-buahan, hewan, dan tumbuh-tumbuhan namun lebih bervariasi lagi dan diacak dengan tetap menggunakan media Bingo game. Dalam kegiatan ini, peneliti mengajak anak-anak untuk terlibat langsung dalam proses pembelajaran kosa kata bahasa Inggris. Peneliti membagikan media Bingo game kepada anak-anak. Mereka secara aktif menjawab jenis-jenis buah, hewan dan tumbuh-tumbuhan yang disebutkan oleh peneliti dalam bahasa Inggris saat Bingo game berlangsung. Dan sesekali peneliti memberikan petunjuk yang memudahkan mereka untuk menjawab. Pada siklus 2 ini, anak-anak semakin aktif mengikuti pembelajaran, semakin termotivasi dan antusias mengikuti Bingo game. Kemampuan mereka dalam mengucapkan kata dalam bahasa Inggris pun semakin baik pula. Setelah kegiatan di siklus 2 usai, peneliti melaksanakan pos tes 2 untuk menguji tingkat kemampuan mereka dalam penguasaan kosa kata. Materi yang diujikan adalah terkait dengan materi yang sebelumnya sudah diberikan oleh peneliti yaitu buah-buahan, hewan, dan tumbuhtumbuhan. Materi uji tersebut diberikan kepada anak-anak dalam bentuk gambar-gambar menarik yang diacak dan mereka diminta untuk menebak gambar-gambar tersebut serta mengucapkannya dalam bahasa Inggris.

Hasil penelitian memperlihatkan perubahan yang positif dalam penerapan Bingo game karena dalam hal ini anak-anak menjadi lebih semangat, antusias, aktif dan kreatif dalam merespon jalannya proses pembelajaran, serta percaya diri dalam mempelajari kosa kata bahasa Inggris. Hal tersebut mengakibatkan kondisi kelas pun juga menjadi lebih kondusif, menyenangkan, dan efektif. Penerapan Bingo game ini telah meningkatkan pula penguasaan kosa kata dan pengucapan bahasa Inggris mereka. Sebelum penerapan Bingo game, mereka mempelajari kosa kata bahasa Inggris dengan media yang selalu sama yang digunakan oleh guru yaitu flash card dan hal tersebut membuat mereka bosan, tidak tertarik lagi, kurang termotivasi, dan kurang antusias. Hal tersebut juga berdampak pada hasil yang kurang memuaskan yang didapatkan dalam proses pembelajaran kosa kata tersebut. Penggunaan Bingo game dapat dijadikan media pembelajaran kosa kata bahasa Inggris yang efektif, khususnya di TK NDM, karena Bingo game merupakan permainan yang menarik dan menyenangkan bagi segala usia. Selain itu belum Bingo game belum pernah diterapkan dalam proses pembelajaran di TK NDM. Apabila digunakan untuk anak usia dini, seperti di TK NDM, cukup disesuaikan materinya dengan kemampuan dan usia mereka. Bingo game juga telah banyak digunakan dalam penelitian yang dilaksanakan oleh beberapa peneliti. Namun, dalam penelitian mereka, Bingo game diterapkan pada siswa di sekolah dasar dan bukan di pendidikan anak usia dini. Seperti artikel ilmiah yang ditulis oleh Rahmasari (2021) dengan judul 'Improving Students' Vocabulary Mastery through Bingo Games' yang merupakan hasil penelitian di kelas 4 SDK Petra Madiun; Sudrajat \& Herlina (2015) dengan judul 'Meningkatkan Pemahaman Kosakata Bahasa Inggris melalui Metode Permainan Bingo' yang merupakan hasil penelitian di kelas 2 SD Laboratorium Sekolah Dasar PGSD Jakarta; dan Wahyuni \& Syafei (2016) dengan judul 'The Use of Action Bingo Game in Teaching Vocabulary to Elemengary School Students' yang merupakan hasil penelitian di kelas 6 SD. Semua hasil penelitian tersebut yang ditulis dalam artikel ilmiah menunjukkan tentang 
efektifitas dari penerapan Bingo game dalam pembelajaran kosa kata bahasa Inggris di sekolah dasar. Hal tersebut dapat disamakan pula dengan hasil penelitian di TK NDM yangmana penerapan Bingo game di TK tersebut dapat dilaksanakan dengan baik dan efektif serta mampu meningkatkan penguasaan kosakata anak usia dini. Dengan begitu, Bingo game dapat pula diterapkan pada anak usia dini dan bukan saja pada siswa sekolah dasar serta perlu disesuaikan dengan karakteristik anak usia dini dan materi yang hendak disampaikan oleh guru. Peningkatan motivasi anak usia dini di TK NDM selama proses belajar mengajar juga memberikan kontribusi positif. Mereka menjadi lebih aktif dan antusias dalam belajar proses. Mengajarkan kosakata melalui permainan Bingo dapat mengurangi kebosanan dan juga meningkatkan partisipasi, aktivitas, dan interaksi anak dalam proses belajar mengajar.

\section{SIMPULAN}

Media Bingo game menjadi salah satu alternatif media pembelajaran terbaik yang diterapkan dalam proses pembelajaran kosa kata bahasa Inggris khususnya di TK karena dapat meningkatkan penguasaan kosa kata anak-anak usia dini. Keterlibatan dan interaksi anak-anak usia dini juga meningkat dengan antusiasme selama permainan ini berlangsung. Guru dapat menggunakan media Bingo game untuk mengenalkan bahasa Inggris kepada anak-anak usia dini sehingga dapat menghindarkan kebosanan pada anak-anak terhadap penggunaan media pembelajaran yang selalu sama dan kurang bervariasi.

\section{UCAPAN TERIMA KASIH}

Ucapan terima kasih ditujukan pada Universitas Slamet Riyadi Surakarta, TK NDM Kauman dan berbagai pihak yang telah membantu terlaksananya penelitian.

\section{DAFTAR PUSTAKA}

Aisyah, N. S., Hidayatur Rahma, N. A., \& Yugafiati, R. (2019). Improving Student'S Vocabulary Mastery Through Cooperative Script on Descriptive Text. PROJECT $\begin{array}{llll}\text { (Professional Journal of English } & \text { Education), }\end{array}$ https:// doi.org/10.22460/project.v2i2.p181-186

Ermawati, E. A., Trianasari, E., \& Banyuwangi, P. N. (2019). Bingo game: hidden treasure among heap of woods (the effectivity of a game in improving students' vocabulary mastery). Journal of Applied Studies in Language, 3(1), 37-42. https:// doi.org/10.31940/jasl.v3i1.1159

Inten, D. N. (2018). Meningkatkan Penguasaan Kosakata Anak Usia Dini melalui Puisi Lagu Anak. Golden Age: Jurnal Pendidikan Anak Usia Dini, 2(2), 45-52. https:// doi.org/10.29313/ga.v2i2.4437

LIU Shuang, \& LIU Jin-xia. (2015). The Application of Games in English Vocabulary Teaching in Kindergartens. Sino-US English Teaching, 12(8), 561-567. https://doi.org/10.17265/1539-8072/2015.08.003

Liyana, A., \& Kurniawan, M. (2019). Speaking Pyramid sebagai Media Pembelajaran Kosa Kata Bahasa Inggris Anak Usia 5-6 Tahun. Jurnal Obsesi : Jurnal Pendidikan Anak Usia Dini, 3(1), 225. https:/ / doi.org/10.31004/obsesi.v3i1.178

Lube, C. I., \& Nuraeni, S. (2020). Improving English Vocabulary Mastery Through Word Game. PROJECT (Professional Journal of English Education), 3(1), 109. https:// doi.org/10.22460/project.v3i1.p109-113

Muspawi, M., Suryani, I., \& Rahayu, A. Y. (2020). Penerapan Permainan Scrabble Untuk Meningkatkan Penguasaan Kosakata Anak. Jurnal Sains Sosio Humaniora, 4(1), 1-9. https:// doi.org/10.22437/jssh.v4i1.9761

Nuraeningsih, N., \& Rusiana, R. (2016). Improving Students' Vocabulary Mastery through TPR Storytelling. IJELTAL (Indonesian Journal of English Language Teaching and Applied Linguistics), 1(1), 49. https:// doi.org/10.21093/ijeltal.v1i1.3 
Nurzaman, I., Yasbiati, Y., \& Rahmattya, E. (2017). Penggunaan Permainan Pesan Gambar Berantai untuk Meningkatkan Kosakata Bahasa Inggris Anak Usia Dini. Jurnal Paud Agapedia, 1(1), 40-52. https:/ / doi.org/10.17509/jpa.v1i1.7159

Putri, F. S., \& Kareviati, E. (2021). Students' Responses Toward the Implementation of Bingo Game With Scientific Approach in Teaching Writing Descriptive Text. PROJECT (Professional Journal of English 392. https:// doi.org/10.22460/project.v4i3.p392-396

Qomariyah, S. S., \& Utama, I. M. P. (2020). Bingo Games in students' vocabulary and reading comprehension. EnJourMe (English Journal of Merdeka): Culture, Language, and Teaching of English, 5(2), 170-177. https:// doi.org/10.26905/enjourme.v5i2.5056

Rahman, A. A., \& Angraeni, A. (2020). Empowering learners with role-playing game for vocabulary mastery. International Journal of Learning, Teaching and Educational Research, 19(1), 60-73. https:/ / doi.org/10.26803/ijlter.19.1.4

Rahmasari, B. S. (2021). Improving Students' Vocabulary Mastery Through Bingo Games. Jurnal Kependidikan: Jurnal Hasil Penelitian Dan Kajian Kepustakaan Di Bidang $\begin{array}{llll}\text { Pendidikan, Pengajaran Dan } & \text { Pembelajaran, }\end{array}$ https://doi.org/10.33394/jk.v7i1.2696

Rizkiani, S., Bhuana, G. P., \& Rizqiya, R. S. (2019). Pemanfaatan Barang Bekas Sebagai Media Pembelajaran Kosa Kata Bahasa Inggris. JURNAL CEMERLANG : Pengabdian Pada Masyarakat, 2(1), 57-70. https://doi.org/10.31540/jpm.v2i1.728

Roswati, E. (2020). Meningkatkan Kosakata Anak Usia Dini Melalui Permainan Chinese Whispers. Jurnal PG-PAUD Trunojoyo: Jurnal Pendidikan Dan Pembelajaran Anak Usia Dini, 7(1), 32-36. https:/ / doi.org/10.21107/pgpaudtrunojoyo.v7i1.6420

Setiawan, C. (2019). Improving Students' Vocabulary Mastery Through Listening Song. PROJECT (Professional Journal of English Education), 2(3), 392. https:// doi.org/10.22460/project.v2i3.p392-397

Sudrajat, H. N., \& Herlina, H. (2015). Meningkatkan Pemahaman Kosakata Bahasa Inggris Melalui Metode Permainan Bingo. Jurnal Ilmiah Visi, 10(2), 114-121. https://doi.org/10.21009/JIV.1002.6

Tri Widyahening, Ch. Evy, \& Mafiah, I. (2019). Penggunaan Media Word Webs Dalam Pembelajaran Kosa Kata Bahasa Inggris Di Sdnn 01 Suruh Tasikmadu Karanganyar. ADIWIDYA, 3(2), 50-59.

Tri Widyahening, Christiana Evy, \& Rahayu, M. S. (2021). Pembelajaran Kosa Kata Bahasa Inggris dengan Media Cerita Rakyat bagi Siswa Kelas V Sekolah Dasar. Jurnal Komunikasi Pendidikan, 5(1), 108. https:// doi.org/10.32585/jkp.v5i1.913

Utami, N. U. P., \& Rahman, T. (2020). Penggunaan Media Gambar Untuk Meningkatkan Penguasaan Vocabulary Anak. Jurnal Paud Agapedia, 2(1), 53-65. https://doi.org/10.17509/jpa.v2i1.24388

Wahyuni, D., \& Syafei, A. F. R. (2016). The Use of Action Bingo Game in Teaching Vocabulary to Elementary School Students. Journal of English Language Teaching, 5(1), 163-168. https:// doi.org/10.24036/JELT.V5I1.7299

Wahyuningsih, S. (2019). Kreasi Lagu Anak ( Nursery Rhymes ) Sebagai Media Untuk $\begin{array}{llll}\text { Mengenalkan Bahasa Inggris. Thufula, } & \text { 189-206. }\end{array}$ https://doi.org/10.21043/thufula.v7i2.4998

Yanti, S. (2017). Improving Students Vocabulary Mastery Through Electronic Dictionary. Indonesian EFL Journal, 2(2), 88. https://doi.org/10.25134/ieflj.v2i2.641 